\title{
Analysis of fetal growth restriction in pregnancy in subjects attending in an obstetric clinic of a tertiary care teaching hospital
}

\author{
Ashish Seal $^{1}$, Arup Dasgupta ${ }^{2 *}$, Mousumi Sengupta $^{3}$, Rinini Dastider $^{4}$, Sukanta Sen $^{5}$
}

\begin{abstract}
${ }^{1}$ Department of Obstetrics and Gynecology, Vivekananda Institute of Medical Sciences, Kolkata, West Bengal, India ${ }^{2}$ Department of Anaesthesiology, ICARE Institute of Medical Sciences and Research, Banbishnupur, Purba Medinipur, Haldia, West Bengal, India

${ }^{3}$ Department of Radiology, ${ }^{4}$ Department of Biochemistry, Vivekananda Institute of Medical Sciences, Kolkata, West Bengal, India

${ }^{5}$ Department of Pharmacology, ICARE Institute of Medical Sciences and Research, Banbishnupur, Purba Medinipur, Haldia, West Bengal, India
\end{abstract}

Received: 23 December 2017

Accepted: 24 January 2018

*Correspondence:

Dr. Arup Dasgupta,

E-mail: dradasgupta2015@yahoo.com

Copyright: () the author(s), publisher and licensee Medip Academy. This is an open-access article distributed under the terms of the Creative Commons Attribution Non-Commercial License, which permits unrestricted non-commercial use, distribution, and reproduction in any medium, provided the original work is properly cited.

\begin{abstract}
Background: Intrauterine growth restriction (IUGR) is defined as fetal growth less than the normal growth potential of a specific infant because of genetic or environmental factors. Fetal growth restriction or intrauterine growth restriction is one of the leading causes of perinatal mortality and morbidity in newborns. Fetal growth restriction is a complex multifactorial condition resulting from several fetal and maternal disorders. Objective of present study was to find out incidence of IUGR and assessment and evaluation of different important changes in IUGR.

Methods: Women who attended the Obstetric OPD in their $1^{\text {st }}$ trimester of pregnancy and those who were thought would be able to visit the antenatal clinic for their fortnightly check-up regularly were screened for intrauterine foetal growth retardation. Women with irregular and uncertain menstrual history and where the 1st trimester USG foetal crown rump length did not corroborate with the menstrual gestational age were excluded from this study.

Results: Incidence of IUGR was $18.2 \%$ and $84 \%$ were found to be asymmetrical. IUGR was found to be double among primigravids and women above 30 years. It had been observed that IUGR was associated with certain conditions like short stature (52\%), pregnancy induced hypertension (24\%) and anaemia (12\%).

Conclusions: Thus, early USG screening along with robust screening for maternal BMI, nutritional status, and anaemia can assist the obstetric team in providing early diagnosis, prompt intervention, and better outcome in pregnancy with fetal growth restriction.
\end{abstract}

Keywords: Fetal, Fetus, Intrauterine growth restriction, Outcomes, Pregnancy, Placenta, Small for gestational age

\section{INTRODUCTION}

Intrauterine growth restriction (IUGR) has been defined as the rate of fetal growth that is below normal in light of the growth potential of a specific infant as per the race and gender of the fetus. ${ }^{1}$ It has also been described as a deviation from or a reduction in an expected fetal growth pattern and is usually the result of innate reduced growth potential or because of multiple adverse effects on the fetus. The "normal" neonate is the one whose birth weight is between the 10th and 90th percentile as per the gestational age, gender and race with no feature of malnutrition and growth retardation. The terms "IUGR" and "small for gestational age (SGA)" have been used 
synonymously in medical literature, but there exist small differences between the two. SGA definition is based on the cross-sectional evaluation (either prenatal or postnatal), and this term has been used for those neonates whose birth weight is less than the 10th percentile for that particular gestational age or two standard deviations below the population norms on the growth charts, and the definition considers only the birth weight without any consideration of the in-utero growth and physical characteristics at birth. ${ }^{1}$ Small gestational age (SGA) refers to weight below the 10 percentile for gestational age, corrected for parity and gender, as per the population growth charts. It can be further classified as: ${ }^{2}$

- Moderate: Birth weight in the 3 to 10 percentiles (or 5th to 10th centile)

- Severe: Birth weight less than 3 percentile (or $<5$ th centile)

Ponderal Index (PI) is also used to determine the degree of fetal malnutrition. It is defined as the ratio of body weight to length expressed as

$\mathrm{PI}=\left[\right.$ weight $\left(\right.$ in g) $\mathrm{x} \mathrm{100)} \div\left(\right.$ length $\left.(\text { in cm })^{3}\right]$.

PI of less than 10 percentile reflects fetal malnutrition; PI of less than 3 percentile indicates severe fetal wasting. ${ }^{3}$ An IUGR is a clinical definition and applies to neonates born with clinical features of malnutrition and in-utero growth retardation, irrespective of their birth weight percentile. $^{4,5}$

The incidence of fetal growth restriction varies depending upon the population residing in the developing and developed countries with an incidence rate of 6-30\% to 2 $5 \%$ in these countries, respectively. ${ }^{6,7}$ The highest rate of prevalence of fetal growth restriction is found in Asia, particularly in Southeast Asia, followed by Africa and Latin America. 8

\section{METHODS}

This study on IUGR was conducted in the Department of Obstetrics and Gynaecology of a tertiary care teaching hospital, Kolkata. Women who attended the Obstetric OPD in their $1^{\text {st }}$ trimester of pregnancy and those who were thought would be able to visit the antenatal clinic for their fortnightly check-up regularly were screened for intrauterine foetal growth retardation. Women with irregular and uncertain menstrual history and where the $1^{\text {st }}$ trimester USG foetal crown rump length did not corroborate with the menstrual gestational age were excluded from this study.

A meticulous history was taken. Enquiry was made regarding socio-economic status, addition, contraceptive used and working habits of the pregnant women. Menstrual history includes first date of last menstrual period, cycle, flow, duration and regularity. Obstetrical history highlighted history of abortion, stillbirth, neonatal death, previous birth weight, any complication of the mother including previous pregnancies, during and after delivery.

Assessment of period of gestation i.e. attitude, presentation of foetus, foetal heart sound were done in each antenatal visit, height of fundus and grith of abdomen in centimetres were measured from 20 and 30 weeks respectively, every fortnightly. Ultrasonographic obstetrical examination was done in the first trimester to confirm the gestational period and subsequently at 16, 24, 28, 32 and 36 weeks of gestation to measure the biparietal diameter, head and abdominal circumference and amount of liquor amni.

Monitoring of foetal growth was done clinically by noting the maternal weight gain, height of uterus and girth of abdomen by ultrasonography. Decision regarding delivery was taken in between 36-38 weeks depending on certain jeopardy of fetoplacental unit with special consideration to pediatric attention and monitoring system during labor.

\section{RESULTS}

Total number of deliveries in 9 months study period was 1118 and total number of IUGR cases was 203 with the incidence of $18.25 \%$ of IUGR cases. Twenty five cases of IUGR thus diagnosed were taken up for this study and another 25 cases of normal pregnancy were studied as control. Present study showed $4(16 \%)$ symmetrical and $21(84 \%)$ asymmetrical growth retardation.

Table 1: Age distribution in IUGR and control cases.

\begin{tabular}{|lll|}
\hline Age group & $\begin{array}{l}\text { IUGR cases } \\
(\mathbf{n = 2 5})\end{array}$ & $\begin{array}{l}\text { Control } \\
(\mathrm{n}=25)\end{array}$ \\
\hline Below 19 years & $4(16 \%)$ & $2(8 \%)$ \\
\hline 20-25 years & $4(16 \%)$ & $12(48 \%)$ \\
\hline 26-30 years & $13(52 \%)$ & $9(36 \%)$ \\
\hline 31 years and above & $4(16 \%)$ & $2(8 \%)$ \\
\hline
\end{tabular}

Highest incidence of IUGR was among 26-30 years of age group and majority of the normal pregnancies (48\%) were observed in 20-25 years age group (Table 1 ).

\section{Table 2: Distribution of parity in IUGR and control} cases.

\begin{tabular}{|lll|}
\hline Age group & $\begin{array}{l}\text { IUGR cases } \\
(\mathbf{n = 2 5})\end{array}$ & $\begin{array}{l}\text { Control } \\
(\mathrm{n}=25)\end{array}$ \\
\hline Primigravida & $18(72 \%)$ & $10(40 \%)$ \\
\hline Second Gravida & $2(8 \%)$ & $10(40 \%)$ \\
\hline Third gravida & $2(8 \%)$ & $3(12 \%)$ \\
\hline Fourth garvida and above & $3(12 \%)$ & $2(8 \%)$ \\
\hline
\end{tabular}

It was observed that primigravid, teenage and elderly (more than 30 years) women had double risk of developing IUGR when compared to control group. 
Foetal growth restriction was maximum among primigravida (Table 2).

Table 3: Incidence of IUGR in relation to height of the women.

\begin{tabular}{|ll|}
\hline Height in Cms & IUGR cases $(\mathbf{n = 2 5})$ \\
\hline Below 151 & $13(52 \%)$ \\
\hline $151-160$ & $11(44 \%)$ \\
\hline Above 160 & $1(4 \%)$ \\
\hline
\end{tabular}

Foetal growth restriction was maximum $13(52 \%)$ among women height less than $151 \mathrm{cms}$ (Table 3$)$.
Table 4: Analysis of significant present history in IUGR and control cases.

\begin{tabular}{|lll|}
\hline Causes & $\begin{array}{l}\text { IUGR cases } \\
(\mathbf{n = 2 5})\end{array}$ & $\begin{array}{l}\text { Control } \\
(\mathrm{n}=25)\end{array}$ \\
\hline $1^{\text {st }}$ trimester bleeding P/V & $1(4 \%)$ & - \\
\hline PIH & $6(24 \%)$ & - \\
\hline Anaemia & $3(12 \%)$ & - \\
\hline Heart disease & $1(4 \%)$ & $1(4 \%)$ \\
\hline APH & $1(4 \%)$ & - \\
\hline Abnormal presentation & $2(8 \%)$ & - \\
\hline Multiple pregnancy & $2(8 \%)$ & - \\
\hline Total & $16(64 \%)$ & - \\
\hline
\end{tabular}

Table 5: Analysis of weight gain in IUGR and Control cases in Kilograms.

\begin{tabular}{|c|c|c|c|c|c|c|}
\hline \multirow{2}{*}{$\begin{array}{l}\text { Gestational } \\
\text { week }\end{array}$} & \multicolumn{3}{|c|}{ IUGR \pm Complications ( $\mathbf{n = 2 5 )}$} & \multicolumn{3}{|l|}{ Control $(\mathrm{n}=25)$} \\
\hline & No. of observations & Range & Mean & No. of observations & Range & Mean \\
\hline $13-16$ & 18 & $0.5-1$ & 0.8 & 25 & $0.5-1.5$ & 1.1 \\
\hline $17-20$ & 20 & $0.5-2.5$ & 1.2 & 25 & $0.5-2.5$ & 1.4 \\
\hline $21-24$ & 22 & $1-2.5$ & 0.9 & 25 & $1-2$ & 1.2 \\
\hline $25-28$ & 23 & $0.5-2.5$ & 0.9 & 25 & $0.5-2.5$ & 1.2 \\
\hline $29-30$ & 25 & $0-1.5$ & 0.4 & 25 & $0.5-1.5$ & 0.8 \\
\hline $31-32$ & 25 & (-) $0.5-1.5$ & 0.2 & 25 & $0.5-1$ & 0.6 \\
\hline $33-34$ & 24 & $0-1.5$ & 0.6 & 25 & $0.5-1$ & 0.5 \\
\hline $35-36$ & 23 & $0-1.5$ & 0.8 & 24 & $0-1$ & 0.6 \\
\hline $37-38$ & 20 & $0-0.5$ & 0.5 & 21 & $0-0.5$ & 0.4 \\
\hline $39-40$ & 16 & (-) $0.5-1$ & 0.2 & 12 & (-) $0.5-1$ & 0.3 \\
\hline Total & & & 6.5 & & & 8.1 \\
\hline
\end{tabular}

Significant predisposing factors in present pregnancy were detected in $64 \%$ cases of IUGR against only $4 \%$ in control (Table 4). Significant past and family history was present in $52 \%$ of IUGR cases against $8 \%$ in control. Majority (44\%) of IUGR cases were found among low middle income group in the present study. Mean booking weight in IUGR group was (44.4 kgs), significantly higher than control cases.
Total mean weight gain with treatment in IUGR group was $6.5 \mathrm{Kg}$ from first visit in $1^{\text {st }}$ trimester till delivery (Table 5). An overall improvement was noted in foetal growth by late $3^{\text {rd }}$ trimester with relative increase in symphisis fundal height (Table 6) and girth of abdomen (Table 7).

Table 6: Analysis of symphysis fundal height (in cms) in relation to gestation period in IUGR and Control cases.

\begin{tabular}{|lllllll|}
\hline $\begin{array}{l}\text { Gestational } \\
\text { week }\end{array}$ & No. of observations & Range & Mean & No. of observations & Range & Mean \\
\hline $20-21$ & 20 & $12-17$ & 14.2 & 25 & $12-18$ & 14.8 \\
\hline $22-23$ & 22 & $12-19$ & 16.1 & 25 & $12-22$ & 16.92 \\
\hline $24-25$ & 23 & $14-19$ & 19.2 & 25 & $15-22$ & 19.57 \\
\hline $26-27$ & 24 & $14-21$ & 20.6 & 25 & $15-25$ & 21.4 \\
\hline $28-29$ & 25 & $16-21$ & 20.7 & 25 & $17-25$ & 23.2 \\
\hline $30-31$ & 25 & $17-22$ & 21.3 & 25 & $19-29$ & 26.4 \\
\hline $32-33$ & 25 & $18-23$ & 22.4 & 25 & $20-31$ & 28.7 \\
\hline $34-35$ & 24 & $20-26$ & 23.7 & 25 & $22-32$ & 30.5 \\
\hline $36-37$ & 20 & $20-27$ & 24.1 & 24 & $24-34$ & 31.2 \\
\hline $38-39$ & 18 & $21-28$ & 25.6 & 20 & $25-35$ & 30.5 \\
\hline $40-41$ & 16 & $21-27$ & 25.2 & 12 & $25-34$ & 30.3 \\
\hline
\end{tabular}


Table 7: Analysis of abdominal girth (in $\mathrm{cm}$ ) in relation to gestational period in IUGR and control cases.

\begin{tabular}{|c|c|c|c|c|c|c|}
\hline \multirow{2}{*}{$\begin{array}{l}\text { Gestational } \\
\text { week }\end{array}$} & \multicolumn{3}{|c|}{ IUGR \pm Complications $(n=25)$} & \multicolumn{3}{|l|}{ Control (n=25) } \\
\hline & No. of observations & Range & Mean & No. of observations & Range & Mean \\
\hline $30-31$ & 25 & $68-84$ & 78.6 & 25 & $69-85$ & 82.5 \\
\hline $32-33$ & 25 & $71-87$ & 82.8 & 25 & $73-92$ & 87.1 \\
\hline $34-35$ & 24 & $72-92$ & 88.1 & 25 & $77-97$ & 91.2 \\
\hline $36-37$ & 20 & $75-96$ & 89.7 & 24 & $83-99$ & 93 \\
\hline $38-39$ & 18 & $77-98$ & 89.1 & 20 & $85-98$ & 93 \\
\hline $40-41$ & 16 & $77-97$ & 91.4 & 12 & $85-99$ & 93.2 \\
\hline
\end{tabular}

Table 8: Ultrasonographic measurement of crown-rump length (in mm) of foetuses in $1^{\text {st }}$ trimester in IUGR and Control cases.

\begin{tabular}{|c|c|c|c|c|c|c|}
\hline \multirow{2}{*}{$\begin{array}{l}\text { Gestational } \\
\text { week }\end{array}$} & \multicolumn{3}{|c|}{ IUGR \pm Complications $(\mathrm{n}=\mathbf{2 5})$} & \multicolumn{3}{|l|}{ Control (n=25) } \\
\hline & No. of observations & Range & Mean & No. of observations & Range & Mean \\
\hline 10 & 9 & $28.8-37.2$ & 33.02 & 5 & $29.2-37.7$ & 33.83 \\
\hline 11 & 6 & $44.6-47.8$ & 46.32 & 11 & $43.1-49.5$ & 46 \\
\hline 12 & 10 & $55.6-60.8$ & 56.88 & 9 & $53.5-61.4$ & 57.67 \\
\hline
\end{tabular}

Measurement of symphysis-fundal height showed significant difference among IUGR and control group (Table 6).

Measurement of girth of abdomen did not show any significant difference between IUGR and control group (Table 7).
There was no difference of CRL in $1^{\text {st }}$ trimester of pregnancy in IUGR and control cases (Table 8).

Difference of BPD was observed more from 28 weeks of gestation in IUGR cases (Table 9). Even relative improvement in USG abdominal circumference measurement at 36 weeks was observed.

Table 9: Analysis of USG measurement of foetal biparietal diameter (in cms) in IUGR and control cases.

\begin{tabular}{|c|c|c|c|c|c|c|}
\hline \multirow{2}{*}{$\begin{array}{l}\text { Gestational } \\
\text { week }\end{array}$} & \multicolumn{3}{|c|}{ IUGR \pm Complications $(\mathbf{n}=\mathbf{2 5})$} & \multicolumn{3}{|l|}{ Control $(\mathrm{n}=25)$} \\
\hline & No. of observations & Range & Mean & No. of observations & Range & Mean \\
\hline 16 & 19 & $2.9-3.3$ & 3.06 & 25 & $2.9-3.5$ & 3.10 \\
\hline 24 & 22 & $5.4-6.2$ & 5.87 & 25 & $5.5-6.4$ & 6.03 \\
\hline 28 & 23 & $6.8-7.6$ & 7.05 & 25 & $7.2-8.1$ & 7.82 \\
\hline 32 & 25 & $7.4-8.2$ & 7.94 & 25 & $7.9-8.6$ & 8.41 \\
\hline 36 & 23 & $8.1-8.5$ & 8.38 & 24 & $8.2-9.5$ & 8.83 \\
\hline
\end{tabular}

Table 10: Analysis of USG measurement of foetal head circumference (in cms) in IUGR and control cases.

\begin{tabular}{|lllllll|}
\hline $\begin{array}{l}\text { Gestational } \\
\text { week }\end{array}$ & \multicolumn{1}{l}{ IUGR \pm Complications $(\mathbf{n = 2 5})$} & & \multicolumn{2}{c|}{ Control $(\mathbf{n = 2 5})$} & Range & Mean \\
\hline 16 & No. of observations & Range & Mean & No. of observations & Rang-12.1 & 10 \\
\hline 24 & 18 & $8-12.3$ & 10.1 & 25 & $15.8-18.3$ & 17.1 \\
\hline 28 & 22 & $14.3-19.7$ & 16.8 & 25 & $22.7-26.1$ & 24.7 \\
\hline 32 & 23 & $18.7-25.4$ & 22.6 & 25 & $26.1-29.3$ & 27.2 \\
\hline 36 & 25 & $24.2-28.1$ & 26.2 & 25 & $29.4-35.1$ & 32.3 \\
\hline
\end{tabular}

No significant difference was observed in head circumference measurement in IUGR and Control cases (Table 10).
Abdominal circumference was found to be less in IUGR group than control cases from 28 weeks onwards in serial USG examination (Table 11). 
Table 11: Analysis of USG measurement of foetal abdominal circumference (in cms) in IUGR and control cases.

\begin{tabular}{|lllllll|}
\hline $\begin{array}{l}\text { Gestational } \\
\text { week }\end{array}$ & IUGR \pm Complications & $(\mathbf{n}=\mathbf{2 5})$ & & \multicolumn{2}{c}{ Control $(\mathbf{n}=25)$} & Mange \\
\hline 16 & No. of observations & Range & Mean & No. of observations & Rangean \\
\hline 24 & 18 & $10.3-13.7$ & 12 & 25 & $10.2-13.8$ & 12.1 \\
\hline 28 & 22 & $16.8-21.1$ & 18.6 & 25 & $16.6-21.5$ & 18.8 \\
\hline 32 & 23 & $18.4-23.7$ & 21.2 & 25 & $24.5-28.6$ & 26 \\
\hline 36 & 25 & $20.8-25.2$ & 22.5 & 25 & $27.2-33.4$ & 29.2 \\
\hline
\end{tabular}

Table 12: Analysis of USG measurement of foetal femoral length (in CMs) in IUGR and control cases.

\begin{tabular}{|lllllll|}
\hline $\begin{array}{l}\text { Gestational } \\
\text { week }\end{array}$ & IUGR \pm Complications $(\mathbf{n = 2 5})$ & \multicolumn{2}{c|}{ Control $(\mathbf{n = 2 5})$} & Range & Mean \\
\hline 16 & No. of observations & Range & Mean & No. of observations & $2.4-2.6$ & 2.52 \\
\hline 24 & 18 & $2.3-2.6$ & 2.53 & 25 & $4.2-4.3$ & 4.25 \\
\hline 28 & 22 & $4.1-4.3$ & 4.21 & 25 & $4.9-5.2$ & 5.05 \\
\hline 32 & 23 & $4.5-5.1$ & 4.85 & 25 & $6-6.3$ & 6.15 \\
\hline 36 & 25 & $5.5-6.1$ & 5.83 & 25 & $6.9-7.1$ & 7 \\
\hline
\end{tabular}

Femur length was found to be shorter in IUGR group than control cases after 32 weeks gestation. A gradual increase in femur length till 36 weeks was noted in normal pregnancy (Table 12).

Earliest detection of oligohydramnios and suspicion of IUGR was possible at 16 weeks. Earliest diagnosis of
IUGR was done at 28 weeks, but majority (64\%) were diagnosed between 32-34 weeks. Vaginal delivery was conducted in $32 \%$ of IUGR cases and LSCS in $68 \%$, out of which $52 \%$ were delivered electively. Caesarean section rate was 2.5 times more in IUGR group as compared to control for obvious reasons.

Table 13: Analysis of birth weight and sex of IUGR and control cases.

\begin{tabular}{|llllllll|}
\hline & \multicolumn{2}{l}{ Weight of neonate in Kgs } & \multicolumn{3}{c|}{ Sex } \\
& $\mathbf{2}$ or less & $\mathbf{2 . 1 - 2 . 5}$ & More than 2.5 & Range & Mean & Male & Female \\
\hline IUGR cases $(\mathrm{n}=25)$ & $4(16 \%)$ & $17(68 \%)$ & $4(16 \%)$ & $1.25-2.85$ & 2.21 & $8(32 \%)$ & $17(68 \%)$ \\
\hline Control cases $(\mathrm{n}=25)$ & - & - & $25(100 \%)$ & $2.5-3.3$ & 2.88 & $14(56 \%)$ & $11(44 \%)$ \\
\hline
\end{tabular}

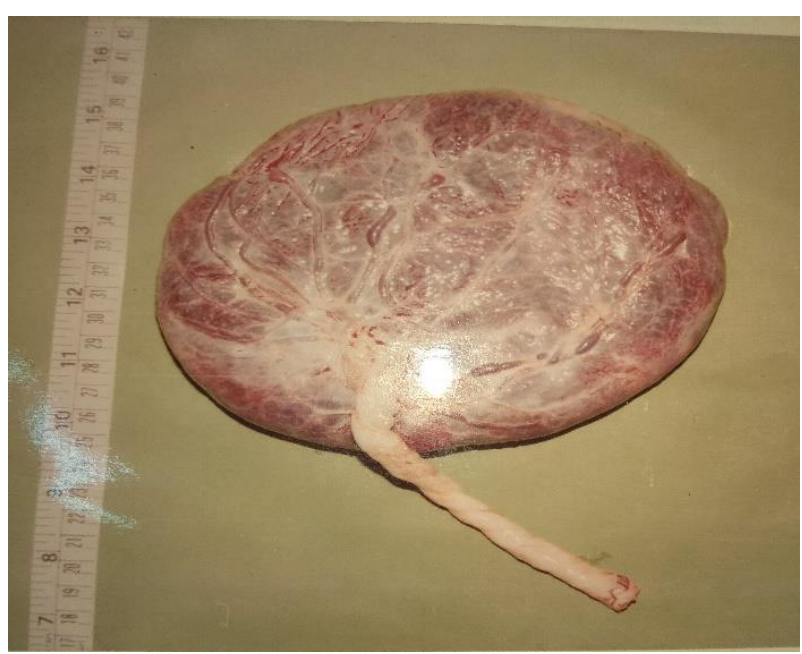

Figure 1: Small placenta weighing $350 \mathrm{gms}$ in an IUGR pregnancy.

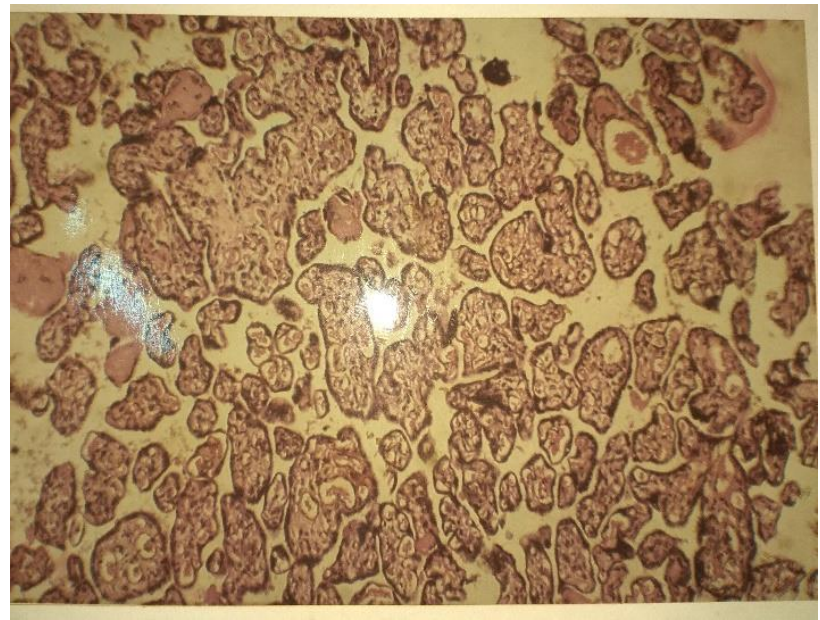

Figure 2: Microscopic examination shows normal placental histopathological features in an IUGR pregnancy. 
Majority of IUGR babies (68\%) weighed between 2.1-2.5 $\mathrm{Kgs}$ with a range of $1.25-2.85 \mathrm{Kg}$, whereas control normal babies weighed $2.5-3.3 \mathrm{Kgs}$. The range and mean of birth weight of IUGR babies show lower value than the control group. The interesting feature is the appreciable high incidence of female babies in IUGR pregnancy (Table 13). In IUGR group majority (64\%) of placenta were below $300 \mathrm{gm}$, with mean weight of 295 gm; whereas control group had mean placental weight of 510 gms. Mean weight of placenta of IUGR babies were significantly low as compared to control group. In IUGR group perinatal mortality was $2(8 \%)$, whereas in normal pregnancy there was no perinatal death.

\section{DISCUSSION}

Intrauterine growth restriction (IUGR), which predisposes the child to metabolic disturbances during the neonatal period and to alterations in somatic and neurocognitive development during childhood, is one of the main public health problems in developing countries. ${ }^{10,11}$ It is also responsible for diseases that affect adults, such as cardiovascular disorders, hypertension, and non-insulin-dependent diabetes. ${ }^{12}$ The IUGR rate in developing countries is six times higher than in developed ones, and it is estimated that $23.8 \%$ of all newborn infants, $\sim 30$ million, are born with IUGR every year worldwide. ${ }^{13}$

In the present study asymmetrical IUGR was found in $84 \%$ cases. Barker DJ, et al (1989) reported $70 \%$ asymmetrical IUGR babies. ${ }^{14}$ So majority of the IUGR babies were found to be asymmetrical having better prognosis and better future. Incidence of low birth weight babies is $16.8 \%$ in some studies in India. ${ }^{15}$ Primiparity is an independent risk factor for intrauterine growth restriction. ${ }^{16}$ This coincides with our present study analysis where most pregnant women with IUGR were primigravidae $(72 \%)$.

Fetal growth restriction or intrauterine growth restriction (IUGR) cannot be termed into a specific disease entity per se, but it is rather a complex multi-factorial condition. It is manifested as a result of several fetal and maternal disorders. ${ }^{17}$ The factors affecting fetal growth restriction are the nature of the etiological agents and the duration of gestation. ${ }^{18}$ These factors can be classified into maternal, fetal, placental, and environmental factors. The maternal factors consist of preeclampsia, diabetes mellitus, and heart diseases. The fetal factors include aneuploidy, chromosomal abnormalities, and multiple gestation. The placental factors comprise placenta previa, placenta accreta, abruptio placentae, and finally theenvironmental factors, such as smoking, drugs, maternal malnutrition, illiteracy and low socio-economic status are involved in fetal growth restriction. ${ }^{19,20}$ The fetal growth restriction makes the fetus more prone to perinatal morbidity and mortality due to the failure of a fetus to attain its complete growth potential. ${ }^{21}$ It also increases its risk for long term consequences, such as coronary heart disease, type-2 diabetes mellitus, hypertension, and metabolic syndrome..$^{22,23}$ Therefore, having knowledge of predisposing extrinsic factors may help in early diagnosis, prompt intervention and better management, which can ultimately lead to good obstetric care during fetal growth restriction.

Szentpéteri I et al conducted a study to describe placental gene expression patterns of endoglin in pregnancies with Intrauterine Growth Restriction (IUGR) compared to normal pregnancies. ${ }^{24,25}$ IUGR newborns have typical but varied clinical features. ${ }^{26}$

Gestational age is difficult to determine as the physical criteria are often unreliable when used alone but reliability improves along with neurologic assessment, especially in the absence of neurological insults. ${ }^{5}$ These newborn are faced with many problems after birth. Severely affected IUGR infants, deprived of oxygen and nutrients, may have difficult cardiopulmonary transition with perinatal asphyxia, meconium aspiration, or persistent pulmonary hypertension. Immediate neonatal complications include hypothermia, hypoglycemia, hyperglycaemia, hypocalcaemia, polycythaemia, jaundice, feeding difficulties, feed intolerance, necrotizing enterocolitis, late onset sepsis, pulmonary haemorrhage and so on. ${ }^{5} \mathrm{Katz}$ et al in a pooled analysis of 20 cohorts (total population 2015019 live births) from Asia, Africa, and Latin America studied the mortality risk in preterm and small for gestational age infants in low income and middle income countries. ${ }^{27}$

Kramer et al, in their systematic review of 16 RCTs and quasi experimental studies on balanced energy protein supplementation to pregnant women reported reduction in incidence of SGA (RR 0.66, 95\% CI 0.49-0.89), stillbirths (RR 0.62 , 95\% CI 0.40-0.98) and improved birth weight (Mean difference of 73g, 95\% CI 30-117). ${ }^{28}$

Cochrane systematic review of 21 RCTs on multiple micronutrient supplementation to pregnant women in comparison with two or fewer micronutrients resulted in a significant effect on low birth weight (RR $0.88,95 \%$ CI 0.85-0.91), SGA (RR 0.89, 95\% CI 0.83-0.96) and preterm birth (RR $0.97,95 \%$ CI 0.94-0.99). ${ }^{29}$

Significant past medical history was found in $52 \%$ of the IUGR group in comparison to $8 \%$ in control group, $24 \%$ of foetal growth retardation cases had history of infertility. Ghazi et al also observed increase incidence of IUGR among pregnant women with history of infertility, which corroborates with finding of present cases. According to Sharma SR et al and Villar J et al IUGR is found commonly in low income group..$^{30-32}$

Fundal height traditionally measured in relation to umbilicus and xiphisternum is of little value in predicting the fetal growth. Some workers have found that symphysis fundal height (SFH) measurements could be useful in screening pregnancies for growth retardation. In 
the present study fundal height measurement showed more positive diagnostic value than abdominal girth, this finding is in accordance with the findings of Mathai and Indira. $^{33,34}$

USG is a very important investigation in diagnosis and monitoring of IUGR. BPD was found to lag behind in IUGR group than that of control group from 28 weeks onwards in the present study. The head circumference followed the same pattern of growth like BPD in both IUGR and normal group. The present study corroborates with the findings of Campbell. ${ }^{35}$ Significant decrease in abdominal circumference was observed in the present study in the IUGR group it was $26.4 \mathrm{cms}$ at 36 weeks when compared to control group of normal pregnancies (32.5 cms); whereas earliest difference was observed at 28 weeks, it became significant at 32 weeks. This observation correlates well with the findings of Chitty LS et al, who could diagnose $87 \%$ of IUGR at 32 weeks by USG abdominal circumference alone. ${ }^{36}$

Vaginal delivery was conducted in $32 \%$ of the IUGR cases and lower segment caesarean section in $68 \%$, out of which $52 \%$ were delivered electively, in control group there were only $12 \%$ elective caesarean sections. In the present study only 4 babies $(16 \%)$ were of less than 2 Kgs weight, out of which $2(50 \%)$ died and survived $50 \%$. In IUGR group majority $(64 \%)$ of placenta were below 300 gms, with mean weight of 295 gms, whereas control group had mean placental weight of $510 \mathrm{gms}$, which conforms with the observation of Fox. ${ }^{37}$

\section{CONCLUSION}

Incidence of IUGR was $18.2 \%$, in the present study $84 \%$ found to be asymmetrical. Foetal growth retardation was found to be double among primigravids, teenage and women above 30 years. In this study ultrasonographic abdominal circumference and $\mathrm{HC} / \mathrm{AC}$ ratio were found to be of immense importance in monitoring IUGR. In this study earliest suspicion by detecting oligohydramnios at 16 weeks were possible by USG, otherwise early diagnosis of growth retardation was done at 28-30 weeks of gestation, by and large IUGR was diagnosed clinically by measuring the fundal height, and by detecting remarkable less amount of liquor. Female babies were found to be more $(68 \%)$ among IUGR series. Placenta in IUGR group was significantly lighter in weight than the control group. Measures to reduce the incidence of IUGR should include the establishment of public policies that are properly directed during pregnancy health check-up. Poor socioeconomic status, poor care of the girl child, medical and obstetric disorders complicating pregnancy contribute to a significant proportion of IUGR in developing countries. Of late genetic factors affecting the mother, placental and fetus are increasingly reported. Finally, long-term follow-up of these growth retarded children is important in order to assess the success of any management programme.
Funding: No funding sources

Conflict of interest: None declared

Ethical approval: The study was approved by the Institutional Ethics Committee

\section{REFERENCES}

1. Battaglia FC, Lubchenco LO. A practical classification of newborn infants by weight and gestational age. J Pediatr. 1967;71:159-63.

2. Lee PA, Chernausek SD, Hokken-Koelega AC, Czernichow P. International Small for Gestational Age Advisory Board (2003) International Small for Gestational Age Advisory Board consensus development conference statement: management of short children born small for gestational age. Pediatrics. 2001;111:1253-61.

3. Alexander GR, Himes JH, Kaufman RB, Mor J, Kogan M. A United States national reference for fetal growth. Obstet Gynecol. 1996;87:163-8.

4. Sharma D, Shastri S, Sharma P. Intrauterine growth restriction: antenatal and postnatal aspects. Clinical Medicine Insights Pediatrics. 2016;10:67-83.

5. Murki S, Sharma D. Intrauterine growth retardation: a review article. J Neonatal Biol. 2014;3:135.

6. Saleem T, Sajjad N, Fatima S, Habib N, Ali SR, Qadir M. Intrauterine growth retardation-small events, big consequences. Ital J Pediatr. 2011 Sep;37:41.

7. Scott KE, Usher R. Fetal malnutrition: its incidence, causes, and effects. Am J Obstet Gynecol. 1966;94(7):951-63.

8. Imdad A, Yakoob MY, Siddiqui S, Bhutta ZA. Screening and triage of intrauterine growth restriction (IUGR) in general population and high risk pregnancies: a systematic review with a focus on reduction of IUGR related stillbirths. BMC Public Health. 2011 Apr;11 Suppl 3:S1.

9. Horta BL, Victora CG, Menezes AM, Halpern R, Barros FC. Low birth weight, preterm births and intrauterine growth retardation in relation to maternal smoking. Paediatr Perinat Epidemiol. 1997 Apr;11(2):140-51.

10. Ashworth A. Effects of intrauterine growth retardation on mortality and morbidity in infants and young children. Eur J Clin Nutr. 1998:52(suppl 1):S34-S42.

11. Leitner Y, Valevski FA, Geva R, Bassan H, Posner E, Kutai M, et al. Six year follow-up of children with intrauterine growth retardation: long-term, prospective study. J Child Neurol. 2000;15:781-6.

12. Barker DJ. Fetal origins of coronary heart disease. BMJ. 1995;311:171-4

13. de Onis M, Blossner M, Villar J. Levels and patterns of intrauterine growth retardation in developing countries. Eur J Clin Nutr 1998; 52 (suppl 1):S5-S15 5 .

14. Barker DJ, Osmond C, Golding J, Kuh D, Wadsworth ME. Growth in utero, blood pressure in 
childhood and adult life and mortality from cardiovascular disease. BMJ. 1989;298:564-7.

15. Pillay P, Janaki S, Manjila C. A comparative study of gravidogram and ultrasound in detection of IUGR. J Obstet Gynaecol India. 2012;62(4):409-4128.

16. Shoham-Vardi I, Leiberman JR, Kopernik G. The association of primiparity with intrauterine growth retardation. Eur J Obstet Gynecol Reprod Biol. 1994;53(2):95-101.

17. Resnik R. Intrauterine growth restriction. Obstet Gynecol. 2002 Mar;99(3):490-6.

18. Torche F. The effect of maternal stress on birth outcomes: exploiting a natural experiment. Demography. 2011 Nov; 48(4):1473-91.

19. Pike K, Jane Pillow J, Lucas JS. Long term respiratory consequences of intrauterine growth restriction. Semin Fetal Neonatal Med. 2012 Apr;17(2):92-8.

20. Muthayya S. Maternal nutrition and low birth weight-what is really important? Indian J Med Res. 2009 Nov;130(5):600-8.

21. Bamfo JE, Odibo AO. Diagnosis and management of fetal growth restriction. J Pregnancy. 2011;2011:640715.

22. Ornoy A. Prenatal origin of obesity and their complications: gestational diabetes, maternal overweight and the paradoxical effects of fetal growth restriction and macrosomia. Reprod Toxicol. 2011 Sep; 32(2):205-12.

23. Sawant LD, Venkat S. Comparative Analysis of Normal versus Fetal Growth Restriction in Pregnancy: The Significance of Maternal Body Mass Index, Nutritional Status, Anemia, and Ultrasonography Screening. Int $\mathrm{J}$ Reprod Med. 2013;2013:671954.

24. Szentpéteri I, Rab A, Kornya L, Kovács P, Brubel R, et al. Placental gene expression patterns of endoglin (CD105) in intrauterine growth restriction. J Matern Fetal Neonatal Med. 2014;27:350-4.

25. Szentpéteri I, Rab A, Kornya L, Kovács P, Joó JG. Gene expression patterns of vascular endothelial growth factor (VEGF-A) in human placenta from pregnancies with intrauterine growth restriction. J Matern Fetal Neonatal Med. 2013;26:984-9.

26. Anderson MS, Hay WW. Intrauterine growth restriction and the small-for-gestational-age infant. In: Neonatology Pathophysiology and Management of the Newborn (5th Edtn). Lippincott Williams and Wilkins, Philadelphia;1999.
27. Katz J, Lee AC, Kozuki N, Lawn JE, Cousens S, Blencowe $\mathrm{H}$ et al. Mortality risk in preterm and small-for-gestational-age infants in low-income and middle-income countries: a pooled country analysis. Lancet. 2013;382:417-25.

28. Kramer MS, Kakuma R. Energy and protein intake in pregnancy. Cochrane Database Syst Rev. 2003:CD000032.

29. Haider BA, Bhutta ZA. Multiple-micronutrient supplementation for women during pregnancy. Cochrane Database Syst Rev. 2012;11:CD004905.

30. Ghazi HA, Spielberger C, Kallen B. Delivery outcome after infertility: a registry study. Fertil Steril. 1991;55:726-32.

31. Sharma SR, Giri S, Timalsina U, Bhandari SS, Basyal B, Wagle $\mathrm{K}$ et al. Low birth weight at term and its determinants in a tertiary hospital of Nepal: a case-control study. PLoS ONE. 2015;10(4):e0123962.

32. Villar J, Belizan JM. The relative contribution of prematurity and fetal growth retardation to low birth weight in developing and developed societies. Am J Obstet Gynecol. 1982;143:793-8.

33. Mathai M, Thomas S, Peedicayil A, Regi A, Jasper $\mathrm{P}$, Joseph R. Growth pattern of the Indian fetus. Int J Gynaecol Obstet. 1995;48:21-4.

34. Indira R, Oumachigui A, Narayan KA, Rajaram P, Ramalingam G. Symphysis-fundal height measurement--a reliable parameter for assessment of fetal growth. Int J Gynaecol Obstet. 1990 Sep;33(1):1-5.

35. Campbell S, Newman GB. Growth of the fetal biparietal diameter during normal pregnancy. J Obstet Gynaecol Br Commonw. 1971;78:513-9.

36. Chitty LS, Altman DG, Henderson A, Campbell S. Charts of fetal size: 3. Abdominal measurements. $\mathrm{Br}$ J Obstet Gynaecol. 1994;101:125-31.

37. Fox H. Invited review. A contemporary approach to placental pathology. Pathology. 1981 Apr;13(2):20723.

Cite this article as: Seal A, Dasgupta A, Sengupta M, Dastider R, Sen S. Analysis of fetal growth restriction in pregnancy in subjects attending in an obstetric clinic of a tertiary care teaching hospital. Int J Reprod Contracept Obstet Gynecol 2018;7:973-80. 